\title{
An overview of glucagon research
}

\author{
Isabel Valverde ${ }^{1}$
}

Received: 14 October 2015 / Accepted: 24 February 2016 / Published online: 26 April 2016

(C) Springer-Verlag Berlin Heidelberg 2016

Keywords Basic areas · Carbohydrate metabolism - Clinical areas · Clinical diabetes - Gastro-entero pancreatic factors . Glucagon $\cdot$ Hormone receptors $\cdot$ Weight regulation and obesity

\section{Abbreviations \\ DPPIV Dipeptidyl peptidase-IV \\ GLI Glucagon-like immunoreactivity \\ GLP Glucagon-like peptide}

Glucagon was discovered in 1923 [1] as a hyperglycaemic factor in insulin extracts from the pancreas. Although it was soon shown to increase circulating glucose by stimulating glycogenolysis in the liver [2], it was not recognised as a hormone for almost four decades. The development of a radioimmunoassay in 1959 [3] made it possible to elucidate the role of glucagon in normal physiological and pathological situations. At the end of the 1960s, intestinal peptides were detected that cross-reacted with some glucagon antibodies (glucagon-like immunoreactivity, GLI); in normal conditions, circulating GLI increases after an oral glucose load whereas pancreatic glucagon is suppressed [4]. After 10 years, these GLI peptides were characterised as glicentin and oxyntomodulin, both being regulators of gastric acid and hydromineral intestinal secretions; in addition, oxyntomodulin is involved in the control of food intake and energy expenditure [5].

Isabel Valverde

ivalverde@fjd.es

1 Dpt. Metabolismo, Nutrición y Hormonas, Fundación Jiménez Díaz, Avda Reyes Católicos, 2, 28040 Madrid, Spain
By 1975, a crucial role for glucagon was proposed in the pathogenesis of diabetes, and it is now known that plasma glucagon concentration is elevated in all described forms of diabetes, including total pancreatectomy, owing to the presence of glucagon produced in gastric alpha cells, and that all agents suppressing glucagon also lower hyperglycaemia [6].

During the last 40 years, glucagon has been accepted as a key hormone in glucose homeostasis. At present, research studies are focusing on hyperglucagonaemia in conditions other than diabetes, on the involvement of glucagon in the regulation of body weight and energy expenditure through its central effects on food intake, body weight and glucose homeostasis, and in the potential of glucagon as a target for type 1 diabetes and obesity, as well as for type 2 diabetes [7].

In 1982, when the number of scientific articles about glucagon was at its zenith (see Fig. 1), knowledge of the preproglucagon molecule in the pancreas and intestine led to the discovery of two peptides analogous to glucagon, named glucagon-like peptide 1 (GLP-1) and 2 (GLP-2) [8, 9], which are produced only in the intestine by post-translational divergence from the processing that occurs in the pancreas [10]. At that point, the number of articles published on glucagon started to decline while the number on GLP-1 and GLP-2 began to rise.

GLP-1 stimulates insulin secretion and inhibits glucagon secretion in the pancreatic islets of Langerhans under hyperglycaemic conditions. GLP-1 receptors have also been found in tissues outside the pancreas, and the extrapancreatic actions of GLP-1 include inhibition of gastric emptying, gastric acid secretion and pancreatic exocrine secretion, as well as cardioprotective and cardiotropic effects [11]. Insulin-like effects on liver, skeletal muscle and adipose tissue [12] and anabolic effects on bone have also been documented [13].

In type 2 diabetes GLP-1 improves glycaemic control without risk of hypoglycaemia, and GLP-1-based therapies using either GLP-1 receptor agonists or dipeptidyl peptidase-IV 
Fig. 1 Dynamics of publications on glucagon and related peptides. The data is based on a PubMed search, representing the number of articles with original data related to glucagon and published in English between 1950 and September 2015

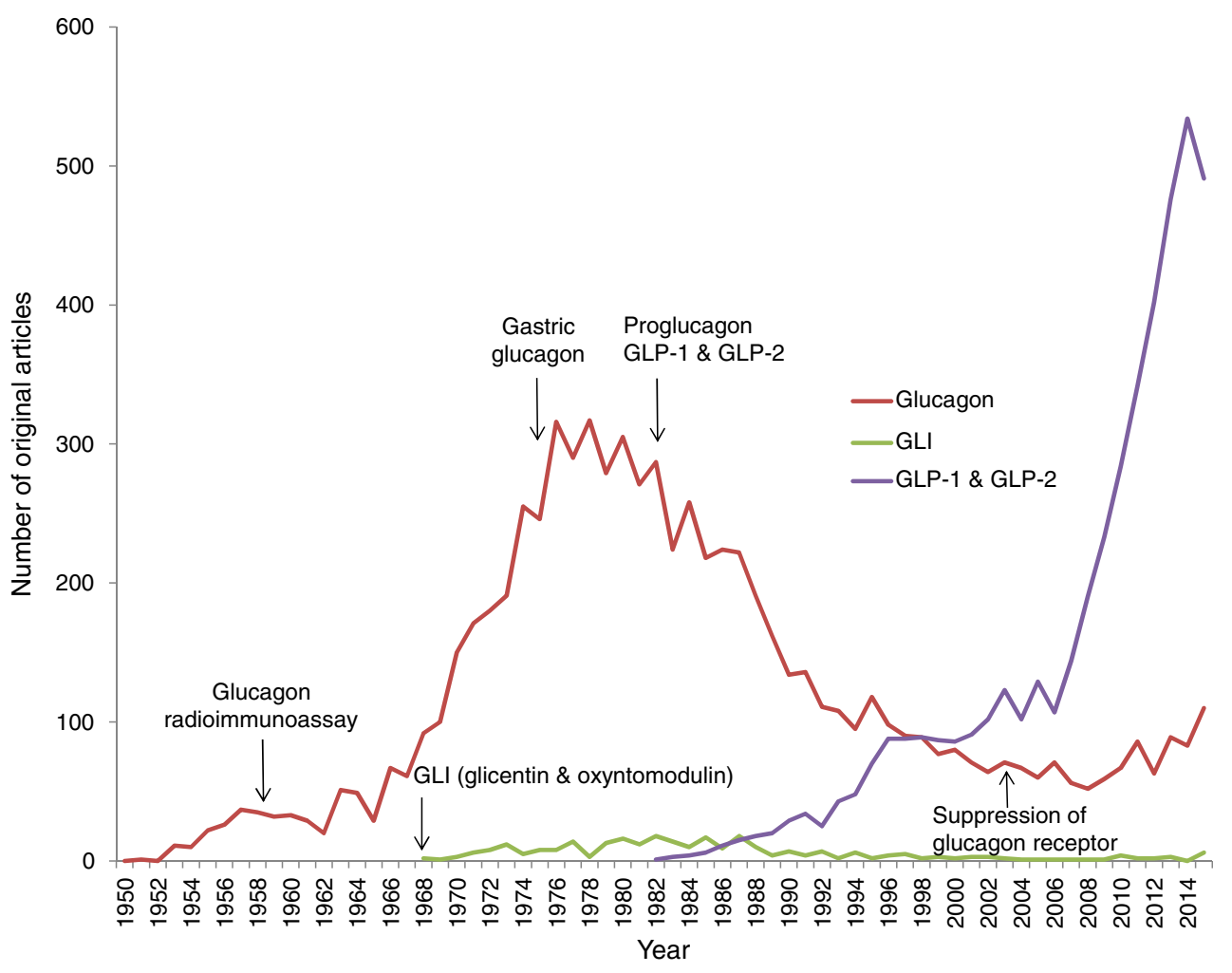

(DPPIV) inhibitors (that delay the degradation of endogenous GLP-1), have become widely used as therapeutic options in type 2 diabetes [14]. GLP-1 also controls appetite and satiety, and DPPIV inhibitors and GLP-1 analogues resistant to degradation by DPPIV have been used in the treatment of obesity. The most apparent role for GLP-2 is the promotion of growth and function of the intestinal mucosa, and it has been targeted for therapies that promote repair and adaptive growth [15].

Insulin resistance and decreased insulin secretion, mainly in response to glucose, were for a long time considered to be responsible for the development of type 2 diabetes; nevertheless, since the 1970 s the participation of glucagon in hyperglycaemia, through its glycogenolytic, gluconeogenic and ketogenic properties, has been established [16]. Moreover, a major role of glucagon in the development of diabetes has been shown in a streptozotocin-induced diabetic mouse model lacking glucagon receptors, which becomes euglycaemic in the absence of insulin treatment [17]. In addition, it was reported that the metabolic abnormalities of diabetes cannot occur in glucagon receptor-null mice, in which virtually all insulin-producing beta cells are destroyed [18]. In another study, NPB112, a novel human monoclonal antibody against the glucagon receptor, lowered glucose levels in a diabetic mouse model with mild and reversible hyperglucagonaemia; this may prove to be a promising therapeutic modality for the treatment of type 2 diabetes [19].

These latter data [17-19], together with the mini-reviews presented here, are examples of how scientific interest in the glucagon molecule is returning. This series of mini-reviews summarises the contributions of leading researchers in this field presented at a symposium 'Novel data on glucagon' at the 51st EASD Annual Meeting in Stockholm in September 2015, and covers the central role of glucagon in suppressing postprandial glucose production (Abraham and Lam [20]), its role as a key factor for development of diabetes (Lee [21]) and its regulatory effect on gluconeogenesis (Miller and Birnbaum [22]).

Duality of interest The author declares that there is no duality of interest associated with this manuscript.

Contribution statement The author was the sole contributor to this paper.

\section{References}

1. Murlin JR, Clough HD, Gibbs GBF, Stokes AM (1923) Aqueous extracts of the pancreas. I. Influence on the carbohydrate metabolism of depancreatized animals. J Biol Chem 56:253

2. Sutherland EW (1950) The effect of the hyperglycemic factor of the pancreas and of epinephrine on glycogenolysis. Recent Prog Horm Res 5:441-437

3. Unger RH, Eisentraut AM, McCall MS, Keller S, Lanz HC, Madison LL (1959) Glucagon antibodies and their use for immunoassay for glucagon. Proc Soc Exp Biol (NY) 102:621-623

4. Unger RH, Ohneda A, Valverde I, Eisentraut AM, Exton J (1968) Characterization of the responses of circulating glucagon-like 
immunoreactivity to intraduodenal and intravenous administration of glucose. J Clin Invest 47:48-65

5. Bataille D, Dalle S (2014) The forgotten members of the glucagon family. Diabetes Res Clin Pract 106:1-10

6. Unger RH (1976) The Banting Memorial Lecture 1975. Diabetes and the alpha cell. Diabetes 25:136-151

7. Ahrén B (2015) Glucagon - early breakthroughs and recent discoveries. Peptides 67:74-81

8. Lund PK, Goodman RH, Dee PC, Habener JF (1982) Pancreatic preproglucagon cDNA contains two glucagon-related coding sequences arranged in tandem. Proc Natl Acad Sci U S A 79:345-349

9. Bell GI, Sanchez-Pescador R, Laybourn PJ, Najarian RC (1983) Exon duplication and divergence in the human preproglucagon gene. Nature 304:368-371

10. Mojsov S, Heinrich G, Wilson IB, Ravazzola M, Orci L, Habener JF (1986) Preproglucagon gene expression in pancreas and intestine diversifies at the level of post-translational processing. J Biol Chem 261:11880-11889

11. Abu-Hamdah R, Rabiee A, Meneilly GS, Shannon RP, Andersen DK, Elahi D (2009) Clinical review: the extrapancreatic effects of glucagon-like peptide-1 and related peptides. J Clin Endocrinol Metab 94:1843-1852

12. Valverde I, Villanueva-Peñacarrillo ML (1996) In vitro insulinomimetic effects of GLP-1 in liver, muscle and fat. Acta Physiol Scand 157:359-360
13. Nuche-Berenguer B, Lozano D, Gutiérrez-Rojas I et al (2011) GLP1 and exendin-4 can reverse hyperlipidic-related osteopenia. J Endocrinol 209:203-210

14. Gallwitz B (2014) Extra-pancreatic effects of incretin-based therapies. Endocrine 47:360-371

15. Janssen P, Rotondo A, Mulé F, Tack J (2013) Review article: a comparison of glucagon-like peptides 1 and 2. Aliment Pharmacol Ther 37:18-36

16. Unger RH, Orci L (1977) Role of glucagon on diabetes. Arch Intern Med 137:482-491

17. Gosmain Y, Masson MH, Philippe J (2013) Glucagon: the renewal of an old hormone in the pathophysiology of diabetes. J Diabetes 5: 102-109

18. Lee Y, Wang MY, Du XQ, Charron MJ, Unger RH (2011) Glucagon receptor knockout prevents insulin-deficient type 1 diabetes in mice. Diabetes 60:391-397

19. Kim WD, Lee YH, Kim MH et al (2012) Human monoclonal antibodies against glucagon receptor improve glucose homeostasis by suppression of hepatic glucose output in diet-induced obese mice. PLoS One 7:e50954

20. Abraham MA, Lam TKT (2016) Glucagon action in the brain. Diabetologia 10.1007/s00125-016-3950-3

21. Lee YH, Wang MY, Yu XX, Unger RH (2016) Glucagon is the key factor in the development of diabetes. Diabetologia 10.1007/ s00125-016-3965-9

22. Miller RA, Birnbaum MJ (2016) Glucagon: acute actions on hepatic metabolism. Diabetologia 10.1007/s00125-016-3955-y 